\title{
CORPORATE GOVERNANCE STRUCTURES IN TRANSITION ECONOMIES - ISSUES AND CONCERNS FOR INDIA
}

\author{
Pankaj Kumar Gupta ${ }^{1}$, Shallu Singh² \\ ${ }^{1}$ Centre for Management Studies, JMI University, Centre for Management Studies Road, Jamia Millia Islamia, \\ Jamia Nagar, Okhla, New Delhi, Delhi 110025, Indie \\ ${ }^{2}$ Delhi College of Arts and Commerce, University of Delhi, Block E, Netaji Nagar, New Delhi, Delhi 110023, Indie
}

To cite this article: GUPTA PANKAJ KUMAR, SINGH SHALLU. 2018. Corporate Governance Structures in Transition Economies - Issues and Concerns for India. Acta Universitatis Agriculturae et Silviculturae Mendelianae Brunensis, 66(6): 1459-1467.

To link to this article: https://doi.org/10.11118/actaun201866061459

\begin{abstract}
Corporate Governance (CG) has become an important concern for transition economies like India worldwide economies with increasing dynamism of socio-economic environment. Sound system of governance is essential to the economic development of any nation that essentially requires a well-defined legislation, adoption of ethical standards and efficient market structures. Compared to developed economies, CG system in transition economies including BRICS nations is still an unbalanced one and evolving. The objective of this paper is to examine the present status of CG structure in India on certain selected CG parameters, legal and regulatory framework, and compare with the CG structures in other transition economies (BRICS). We use the sample of top 100 companies listed on National Stock Exchange to evaluate them on selected parameters. We examine the Indian corporate sector for transparency, compliances and ethics using reports of national and international agencies. We find that CG structure is weak, unreliable with concentration of controls and instances of growing corporate frauds with poor monitoring system fuelled by a variety of regulators. We suggest that an effective CG code must be developed to overcome these issues in the best interest of society and economy.
\end{abstract}

Keywords: corporate governance, board of directors, stakeholders, legal framework

\section{INTRODUCTION}

A sound system of Corporate Governance (CG) is essential for the economic progress of nations. CG involves a wide range of issues emanating from the interaction of corporate decision making and legal and regulatory environment (Babic, 2001). Corporate Governance from a definitional perspective in the academic and professional literature includes the traits of corporations exhibiting fairness, transparency and accountability ranging from small/micro group of stakeholders to the wider group on a national level. CG deals with the relationship among stakeholders that determine the nature, direction and performance of corporations. The stakeholders' inter-alia includes the employees, shareholders, dealing parties, government and society at large. According to American corporate governance doctrine, the three groups involved in CG are (a) stakeholders providing capital, (b) board of directors and (c) senior executives of the firms (Corpgov, 2013). OECD (2004) points out CG as the system of direction and control of business organizations and the relationship between corporate managers and entrepreneurs. 
World Bank (1999) has focused the relationship of CG to national policy framework. The benefit of CG for nations is widely argued in terms of removal of agency costs (Gedalovic and Shapiro, 2002; Sifuna, 2012) and systematization of stakeholder relationship (Davis and Useem, 2000). CG has also been described as a balancing apparatus (Goergen and Renneboog, 2006) and a trustee for the benefit of stakeholders (Thomson 2009).

In transition economies like India, CG challenges have become multi fold due to the growing significance of corporate form of organizations and increased dependence on various international bodies. The market regulator in India, SEBI (Securities and Exchange Board of India) laid importance on the fairness in the operations of the corporation while dealing the national market place (SEBI, 2003) though the realization has come after scams (Thomson, 2009). Resolution of interest conflict among stakeholders has become important to CG (Marc, 2012) and the resolution mechanism includes the framework of policies, processes, laws and corporate control systems (Financial Times, 2011; Cadbury, 1992). A sound system of corporate governance requires efficient markets, equity in and safeguarding of shareholder's rights with adequate disclosures and transparency (OECD, 2004).

Growing integration of markets, particularly financial markets have opened a plethora of opportunities to transition economies, especially on the front of FDI that can boost the economic development. Impact of CG on FDI is highly observable (Peter, 2004; Swapna, 2007, Balasubramanyam, 2007) and the need for reforms in India is still an immediate one (Kulwinder, 2005). $\mathrm{R}$ and $\mathrm{D}$ efforts significantly affect the FDI (Basu et. al., 2007) and CG system affects the innovation and $R$ and $\mathrm{D}$ efforts in the country, which are the pillars for future sustained economic growth.

Researchers and analysts consent to the view that a good system of corporate governance is essential to nurture the innovation capabilities of which corporations play a major role. We observe that the innovation rankings of BRICS are far lower as compared to the developed economies (Tab. I).

The dimensions of good governance inter-alia include "the shareholders' rights and role in major corporate decisions, governance safeguards protecting shareholders from undue board control and entrenchment, and corporate transparency on ownership stakes, compensation, audits, and financial prospects" (GII, 2017).

CG has been used as a mechanism to gather competitive advantage in large financial institutions (Gowd et al., 2011) and is equally important for Micro Finance Institutions (MFIs) in achieving their objectives (Das, 2011) in an Indian context. Questions are raised on the way regulators handle the problem of governance (Varma, 1997; Chakrabarti et al., 2008; Solanki, 2012). It has been argued that CG in India is comparable to other BRICS counterparts and the Indian banking sector is ranked on a higher footing in terms of ease of credit provision, use of technology and lowering non-performing assets. Researchers in India have appreciated the functioning of NSE, BSE and SEBI but lay emphasis on the quality of corporate governance to improve country growth rates particularly after the Sarbanes-Oxley enforcements.

In US, UK and other developed markets, economic progress is linked to the system of corporate governance (Coffee, 2001; Rajan and Zingales, 2003). In order that transition economies improve their CG status, much work is needed for law enforcement and evaluating the sanctity of disclosures (Daines and Jones, 2007; Milhaupt and Pistor, 2008), and investors' confidence (Roe and Siegel, 2009; Jackson and Roe, 2009). Kar (2011) argues that behavioural dimensions of individuals can exert a large influence on the CG structural framework. The sensitivity of these factors is sometimes ignored while formulating and implementing the best practices in corporate governance.

Similar to emerging markets, Indian companies' honour respect for the views of seniors and elders, which is contrary to the legal framework for protection of minority shareholders' interests since they demand that their opinion must be valued and acted upon? Though it is argued that good corporate governance of national importance, yet its direct impact on market performance is not observable in India (Khanna, 2009) contrary to Zuliu (1995) and Arestis et al., (2001). On the securities market front, India is comparable to other developed markets

I: Comparative Innovation Statistics 2017

\begin{tabular}{lccc}
\hline \multicolumn{1}{c}{ Country } & Innovation Index Score & Innovation Input & Innovation Output \\
\hline Switzerland & 67.69 & 69.60 & 65.78 \\
\hline Singapore & 58.69 & 72.25 & 45.14 \\
USA & 61.40 & 68.87 & 53.93 \\
Brazil & 33.10 & 43.47 & 22.72 \\
Russia & 38.76 & 48.21 & 29.31 \\
India & 35.47 & 42.84 & 28.11 \\
China & 52.54 & 54.22 & 50.87 \\
South Africa & 35.80 & 46.85 & 24.74 \\
\hline
\end{tabular}

Source: Global Innovation Index Report 2017 
and also among the emerging markets (NSE, 2005). However, various studies point out the immediate need to overhaul the regulatory framework and government policy (Unadkat, 2017). Studies on the comparison of corporate governance structures and its adoption by multinational vs. domestic enterprises are almost missing in Indian context. We find a research gap to examine the adequacy and effectiveness of legal and regulatory framework and the position of Indian CG structure vis-a-vis other BRIC nations.

The objective of this paper is to examine the CG structure in India on certain selected CG parameters. We also analyse the legal and regulatory framework of CG in India and compare with the CG structures in other transition economies (BRICS). We identify the major concerns, and suggest the policy measures required for India. We divide our analysis into two sections - a) Evaluation of legal and regulatory framework of CG in India, b) Comparison of CG structure in India with some other nations mainly BRICS.

\section{MATERIALS AND METHODS}

\section{Analysis of Legal and Regulatory Framework}

In order to examine the CG structure in India, we analyse the legal and regulatory framework of CG and instances of economic offences for the period 1992-2018. We have selected 100 companies listed on National Stock Exchange (NSE) on the basis of a) market capitalisation, b) turnover, c) visualisation of well-defined component of
CG and d) liquidity of securities. The companies selected for the study represent $73 \%$ of the total market capitalisation on NSE. The indicators of CG used for the study are 1) Number of Independent Directors, 2) Continuance of Statutory Auditors, 3) Number of Directors holding directorship beyond the statutory maximum and 4) companies passing resolutions that are under the scrutiny of media and government agencies and 5) the level of non-promoter holdings. The data has been obtained from Prowess CMIE Database for the period 2012-2017 and various notices, circulars and press news of Economic Offences Wing of Government of India. In addition, we also analyse the reports of various international agencies on CG in India.

\section{RESULTS AND DISCUSSION}

\section{Analysis based on Selected CG Parameters}

Section 149 of the Indian Companies Act 2013, requires that every listed company must have at least one-third of the total number of directors as independent directors. In our sample we find that there are 68 companies which have lesser than 50\% of its board members as independent directors of which 17 companies violate the legal provisions (Tab. II).

Section 139 1) provides that a company is required to appoint its statutory directors for a block of five consecutive years. Section 139 2) of the companies act, 2013 allows a company to appoint an audit firm for two terms of five consecutive years. However,

II: Board Independence $[N=100]$

\begin{tabular}{cc}
\hline \% of Independent Directors & No. of Companies \\
\hline$>60 \%$ & 11 \\
$\leq 60 \%$ but $>50 \%$ & 21 \\
$\leq 40 \%$ but $>33 \%$ & 37 \\
$\leq 33 \%$ & 14 \\
\hline
\end{tabular}

III: Years of continuation of Statutory Auditors [N=100]

\begin{tabular}{cc}
\hline Years of continuation & No. of Companies \\
\hline$>9$ & 38 \\
$\leq 9$ but $>6$ & 39 \\
$\leq 6$ but $>3$ & 18 \\
$\leq 3$ & 05 \\
\hline
\end{tabular}

IV: No. of Independent directors holding directorship of more than 10 companies

\begin{tabular}{cc}
\hline No. of independent Directors & No. of Companies \\
\hline Four & 9 \\
Three & 12 \\
Two & 14 \\
One & 20 \\
\hline
\end{tabular}


V: Directors not attending board meeting $[N=76]$

\begin{tabular}{ccc}
\hline \% age of meetings & No. of directors & No. of Companies \\
\hline$>60 \%$ and $\leq 75 \%$ & $23 \%$ & 27 \\
$\leq 60 \%$ and $>50 \%$ & $20 \%$ & 22 \\
$\leq 50 \%$ and $>33 \%$ & $25 \%$ & 18 \\
$<33 \%$ & $15 \%$ & 9 \\
\hline
\end{tabular}

VI: Externality $[N=100]$

\begin{tabular}{cc}
\hline \% of holdings & No. of Companies \\
\hline$\geq 75 \%$ & 08 \\
$<75 \%$ but $\geq 60 \%$ & 16 \\
$<60 \%$ but $\geq 50 \%$ & 09 \\
$<50 \%$ but $\geq 30 \%$ & 45 \\
$<30 \%$ & 22 \\
\hline
\end{tabular}

VII: Regulations, Institutions and Purpose

\begin{tabular}{|c|c|c|}
\hline Regulations & Institutions/Regulator & Purpose \\
\hline Foreign Exchange Management Act, 2000 & Reserve Bank of India & Management of FOREX Transactions \\
\hline Competition Act, 2002 & Competition Commission of India & Management of Trade Practices \\
\hline $\begin{array}{l}\text { Securities Contract Regulation Act, } 1956 \\
\text { Depositories Act, } 1996\end{array}$ & $\begin{array}{c}\text { Securities and Exchange Board of } \\
\text { India }\end{array}$ & Protection of Interest of Investors \\
\hline $\begin{array}{l}\text { Securities and Exchange Board of India } \\
\text { Act, } 1992\end{array}$ & $\begin{array}{c}\text { Securities and Exchange Board of } \\
\text { India }\end{array}$ & Regulation of Stock Markets \\
\hline Arbitration and Conciliation Act, 1996 & $\begin{array}{c}\text { Arbitration Councils and Quasi } \\
\text { Courts }\end{array}$ & Alternate Dispute Resolution \\
\hline Corporate Governance Codes & CII,SEBI,UTI & CG \\
\hline
\end{tabular}

Tab. III shows that there are 38 companies which have more than 9 years term of statutory auditor and 39 firms have terms between 6 and 9 years. This shows that there is reluctance to change the auditors.

Tab. IV shows that there is a significant number of independent directors who are holding directorships in more than 10 companies which is a violation of the legal norms. The CG quality suffers especially when the multiple directorships refer to group companies or companies under the same management. Also, the attendance of board of directors in meeting is fairly low (Tab. V) and on further enquiry it was found that it is only promoter directors who attend board meetings and take decisions.

There are cases of 11 companies that have passed resolutions violating the Companies Act, 2013 provisions and are under scrutiny of media and government agencies. Out of sample companies, non-promoter holding is relatively lower in Indian companies (Tab. VI).

Gill (2008) has also established that CG structures in India are primarily dominated by ownership and the maintenance of this ownership is due support of financial institutions (Maunder, 2008). The equity concentration leads to high leverage creating a fragility situation for the regulators and policymakers (Kumar, 2000).
Thus, it can be derived that Indian companies lack on selected CG parameters.

\section{Analysis of Regulatory Framework}

It is seen that the policy measures in the recent years have significantly improved the corporate governance in India. These measures include provisions in the Companies Act, 2013 relating to mandatory independent directors on the board, guidelines on Corporate Social Responsibility (CSR) and a variety of disclosures for the benefit of stakeholders. As also observed by Chaudhary et al. (2011), we find that variety of regulations, institutions and framework exists in India (Tab. VII).

In addition, various high powered committees have been set up by the policymakers from time to time like Kumar Mangalam Birla Committee on Corporate Governance in 2000, Naresh Chandra Committee in 2002, and N.R. Narayanamurthy Committee in 2003. In spite of this evolving regulatory framework and multiple regulators, the instances of CG failures can be witnessed from a long list of frauds (Tab. VIII).

We thus raise questions on the adequacy of legal and regulatory framework for CG in India. Studies conducted by various institutions reveal that though the governance structures are fair and at par with global systems (ICSI, 2007), yet 
VIII: Corporate Frauds in India after economic liberalisation

\begin{tabular}{|c|c|c|c|c|c|c|}
\hline $\begin{array}{l}\text { Sl. } \\
\text { no. }\end{array}$ & $\begin{array}{c}\text { Name of } \\
\text { Frauds/Scams }\end{array}$ & Nature of Industry & Year & Fraud Perpetrators & $\begin{array}{l}\text { Quantum of } \\
\text { Fraud } \\
\text { (Rs. in crores) }\end{array}$ & $\begin{array}{c}\text { Whether } \\
\text { SEBI Existed }\end{array}$ \\
\hline 1 & Hashad Mehta & $\begin{array}{l}\text { Capital Market and } \\
\text { Asset Management }\end{array}$ & 1992 & Managing Director & 4000 & Yes \\
\hline 2 & C.R Bhansali & Capital Market & 1992-1996 & Managing Director & 1200 & Yes \\
\hline 3 & Cobbler Scam & Co-operative Society & 1995 & Promoter & 600 & Yes \\
\hline 4 & Virendra Rastogi & Trading co. & 1995-1996 & CEO & 43 & Yes \\
\hline 5 & Abdul Karim Telgi & Printing & 2000 & Promoter & 171.33 & N.A \\
\hline 6 & UTI & Mutual Fund & 2000 & $\begin{array}{l}\text { Chairman, Executive } \\
\text { Director, Stockbroker }\end{array}$ & 32 & Yes \\
\hline 7 & Ketan Parekh & Capital Market & 2001 & Managing Director & 1500 & Yes \\
\hline 8 & Dinesh Dalmia & $\begin{array}{l}\text { Information } \\
\text { Technology }\end{array}$ & 2001 & Managing Director & 595 & Yes \\
\hline 9 & Satyam & $\begin{array}{l}\text { Information } \\
\text { Technology }\end{array}$ & 2009 & $\begin{array}{l}\text { Auditor, Director, } \\
\text { Manager }\end{array}$ & 8000 & Yes \\
\hline 10 & Kingfisher & Airlines & 2016 & Promoter & 9000 & Yes \\
\hline 11 & Nirav Modi & Diamonds & 2018 & Promoter & 20000 & Yes \\
\hline 12 & Vikram Kothari & Pens & 2018 & Promoter & 3600 & Yes \\
\hline
\end{tabular}

there is need to explore the business structures of large organisations according to KPMG reports of 2009 (KPMG, 2009). Similar to our findings, Ray (2018) has also pointed out on the quality of CG as evidenced from the rising bank frauds.

We derive that in India we still have inadequately defined regulations, suboptimal institutional framework and ethical codes. The contradiction between culture and governance is visible in a large number of family-owned businesses. Evidence of dominance can be seen in related-party transactions, dominant shareholder actions, nominations on board, its deliberations and effectiveness. In India, still the top companies, managed and controlled by family members are large in number as compared to other Asian economies (e.g. Other BRICS nations). Formulating a system of good governance is a daunting task primarily because of the existence of complex structures of corporate ownership and lack of professional human resources.

\section{Comparative CG Structures - Other BRICS Nations}

\section{Evolving CG}

The systems of corporate governance that are observable in developed economies are classified into two types (a) market based and (b) group-based system that evolve from varying regulatory and political environment and institutional frameworks, though possessing a system of CG that is internally consistent blended with specialized corporate control (Carati, 2000). In developing economies, including BRICS the CG structures are mainly concentrated towards the ownership and control confined to few stakeholders that may be families, banks and other non-financial corporations, holding companies. The Majority of these nations, specifically those managed by the civil law, has concentrated ownership structures. In this perspective, we present a concise review of the corporate governance structures in BRICS.

In South Africa corporate governance was in bad shape till 1980s. The exposure of South African firms in global capital markets was minimal because of political factors resulting in financial divisions and far from the international product competition. From an era of suboptimal corporate practices, the inefficiencies are being addressed and the regulatory frameworks are brought on par with global standards. Corporate governance standards have impacted both stability and growth prospects (Malherbe and Segal, 2007). Recently, various amendments have been made to the Companies Act, 2008. By these amendments, CG is regulated in South Africa. The King IV report focuses on the combination of (a) the apply-or-explain approach and (b) focus on sustainability that leads to a higher level of accountability and transparency, which are defined as the major CG parameters (Institute of Directors SA, 2016). In spite of these endeavours, still a need for independent directors, better corporate control and need for effective institutions is being felt.

In Russia, unlike developed economies, small shareholders usually have conflict of interest with controlling shareholders over boards, board members, and other issues formed by short 
sightedness, a lack of appropriate business strategies for minority shareholders, and uncontrollable selfishness. With time, companies in Russia decided to structure their own norms of governance, hoping to upgrade their initial public offering or to procure funds from international investors. Further motivation to develop internal governance arose from an increasing interest in mergers and acquisitions and by inspections initiated against Russian companies by regulatory authorities abroad. This change gave rise to the perception of corporate governance as an engine to attract investment, rather than improve operations (Belikov, 2013). Report on the Observance of Standards and Codes (ROSC) initiated by World Bank shows that the update of the Code of Corporate Conduct will modernize the corporate governance framework in Russia. However, this code is criticised for its length and complexity and the unclear requirements to "comply or explain". Ownership disclosure has been a consistent problem of CG in Russian federation.

In China, state wants to maintain controlling ownership interest in firms in multiple sectors and focus is on running the enterprises efficiently apart from maximising wealth. We find cases of conflict of interests between various stakeholders and weak investor protection. Largest shareholder holds major ownership of shares and a significant number of CEO's are heading the board of directors in one or other forms. However, the Corporate Governance standards have been revised frequently for a given corporation if the problems exists (Zöllner, 2013). Razeen (2017) also advocates that China has done remarkable well on "appropriateness of the use of the referents of ownership, control, management, supervisory structure, and executive remuneration" that is being used as CG tools for evaluation.

Habbard (2010) on Brazil says that "there are two prototypes of corporate control and ownership: namely the Rhineland/Japanese concentrated ownership system and the Anglo-American widely-dispersed ownership system." In Brazilian corporations, the CG structures are dominated by majority and the family system. "In realizing long-term economic goals, special attention is paid to the relationship between the state and industry" (Babic and Janosevic, 2001). In spite of the various steps taken at board level by corporations to promote participation in management, the formal governmental policy framework is missing. Corporate governance remains important in Brazil. In the past few years there has been a continuous trend of initiatives and proposals to promote and improve governance practices in the country(Fabiano et al., 2017). These have included proposals for the review and/or creation of corporate governance codes, as well as the approval of new regulations and regulation amendments inspired by corporate governance principles.

Whereas, the CG structiure in India as evident from the findings is weak, India stands on a better footing in terms of CG Index according to a report of Saha rating report of 2017 (Tab. IX). The UK occupies the highest rating and also USA has a very high rating with the largest sample corporations.

$\mathrm{We}$, therefore find that vis-a-vis the emerging economies, we need to evolve an effective code of CG and remove multiple legislations and redundancies in the regulatory framework of CG.

\section{Rationale for CG in Transition Economies}

In transition economies, the control is executed by majority insiders who advocate various benefits of such a structure like minimisation of mismanagement and fraud, longevity of investment etc. However, we find frequent cases of corporate governance failures for obvious reasons of vulnerability. In Europe and Japan, the majority concentration do exists, but the planning and operation of organisation is via a well-defined

IX: WCGI (World Corporate Governance Index) GROUPS

\begin{tabular}{lccc}
\hline Rank & Country & Companies & Average Overall Rating \\
\hline $\mathbf{1}$ & United Kingdom & 395 & 7.60 \\
$\mathbf{2}$ & Canada & 132 & 7.36 \\
$\mathbf{3}$ & Iran & 421 & 7.21 \\
$\mathbf{4}$ & United States & 1,761 & 7.16 \\
$\mathbf{5}$ & New Zealand & 100 & 6.70 \\
$\mathbf{6}$ & Australia & 194 & 6.65 \\
$\mathbf{1 7}$ & Singapore & 52 & 4.82 \\
$\mathbf{2 0}$ & India & 56 & 4.54 \\
$\mathbf{2 3}$ & Malaysia & 28 & 4.21 \\
$\mathbf{2 4}$ & Thailand & 15 & 4.20 \\
$\mathbf{2 9}$ & Brazil & 67 & 3.91 \\
$\mathbf{3 0}$ & Russia & 25 & 3.90 \\
$\mathbf{3 4}$ & China & 91 & 3.37 \\
$\mathbf{3 5}$ & Japan & 392 & 3.30 \\
\hline
\end{tabular}


network that possibly minimises the CG failures and frauds. In US and UK, we find the CG structures guided by the dispersed ownership where the small stakeholders have no inclination or incentive to be involved in the management of corporations.

We argue that the evolution of an effective set of market economy organisations necessary for economic progress. It is obvious that in absence good corporate governance, corporations may not be able to accomplish their ultimate missions of maximizing profits and effectively contributing towards the economic welfare. Corporations cannot operate successfully in the current environment without the adoption of sound principles of corporate governance inherently imbibed among all the stakeholders. Transition economies like BRICS face the problem of mass privatisation where the materialistic behaviours of profit owner's may create havoc and kill the total the total theme of sound corporate governance.

CG brings competitiveness and long-term economic proficiency through - a) authenticity in corporate transactions, b) improvement in the firm management by developing sound corporate strategy and c) transparency in negotiating with creditors, investors and related parties. Sound CG from national perspective helps to develop capital markets and brings public trust (CIPE, 2002). CG represents an ethical conduct originating from the culture and mind-set of management not just with the sole reliance on legal frameworks. Therefore, to bring the economic efficiency, the corporations in transition economies have to build a macro perspective of ethical conduct, representation and transparency of disclosures.

Also, there are conflicting views on the scope of the corporate governance - whether it is confined to corporate or larger touching the macroeconomic frontiers. There are two schools of thoughts to handle the issue of CG in transition economies - a) replicating the system present in the developed economies or b) evolving a customised approach to governance in a transition economy. Replicating the CG mechanism of developed world in transition economies may not be appropriate because of absence of well-organized banking sector and other regulatory bottlenecks.

\section{CONCLUSION}

Transition economies like India essentially require a customised approach to adoption and implementation of globally accepted standards. Given the national concerns, global financial crisis and weakening economies, a choice of CG structure that may be may be optimal for India has to be drawn out of the guiding factors like social systems, market systems, legal systems etc. India has been seriously suffering from the growing corporate frauds that have raised questions on our broader macro policy framework. The obvious question is - Given the increasing instances of corporate frauds in recent years, is our regulatory mechanism perfect or it requires a significant change? Doubts are also raised on the recent amendments to the Companies Act, 2013 requiring companies to invest in Corporate Social Responsibility (CSR) and how it will be implemented. The inbound investments in the country is polarised towards the private sector vis-à-vis the public sector. Does the public sector on which the government has real control have taken sufficient steps to implement the corporate governance that creates a benchmark for the private sector? Also, CG structures in India are primarily dominated by the majority/concentrated shareholders that are able to exercise influence over the political system in the country. There are frequent instances of gross violation of law and market distortions. The recent regulatory changes through appear to be in right direction of promoting governance, yet the practices and business environment are major determinants to its success. We establish that an effective CG code need to be developed that can draw experiences from developed world and overcome the issues that are more prominent in transition economies. The good governance impact can be more visualised in developed countries where the agency conflicts are relatively lesser in quantum and the focus is on developing sustainable organisations. More efforts are need to draw experiences from the nations exhibiting sound governance systems backed by a political will and inclusive growth agenda.

\section{REFERENCES}

ARESTIS, P., DEMETRIADES, P. O. and LUINTEL, K. B. 2001. Financial Development and Economic Growth: The Role of Stock Markets, Journal of Money, Credit and Banking, 33(1): 16-41.

BABIC, V. and JANOSEVIC, S. 2001. How to Improve the Process of Strategic Change Management in Transition Economy Enterprises. In: Strategic Management Society $21^{\text {st }}$ Annual International Conference. San Francisco, October.

BABIC, V. M. 2001. Ključniaspektiupravljačkogrestrukturiranjapreduzeća u uslovimatranzicije, Ekonomist, 332: 133-43.

BABIC, V. M. 2003. Corporate governance problems in transition economy. Social science research seminar. Wake Forest University. [Online]. Available at: http://www.wfu.edu/ caron/ssrs [Accessed: 2017, December 12]. 
BALASUBRAMANYAM, V. N. and SAPSFORD, D. 2007. Does India need a lot more FDI. Economic and Political Weekly, 42(17): 1549-1555.

BASU, P., NAYAK, N. C. and ARCHANA, V. 2007. Foreign Direct Investment in India: Emerging Horizon, Indian Economic Review, 42(2): 255-266.

BELIKOV,I. 2013. Corporate Governance:The Russian Experience and Beyond Russian Institute of Directors. Transparency Lebanon. [Online]. Available at: http://www.transparency-lebanon.org/publications/ casestudiesen.pdf [Accessed: 2013, June 20].

CADBURY, A. 1992. Report of the Committee on the Financial Aspects of Corporate Governance. London: Gee.

CARATI, G. and TOURANI RAD, A. 2000. Convergence of Corporate Governance Systems, Managerial Finance, 2610: 66-86.

CHAKRABARTI, R., MEGGINSON, W. L. and YADAV, P. K. 2008. Corporate Governance in India. Journal of Applied Corporate Finance, 20(1): 59-72.

CHAUDHURY, S. K., DAS, S. K. and MISHRA, D. P. 2011. Corporate Governance Practices in Selected Indian Financial Institutions. European Journal of Business and Economics, 5: 39.

CIPE. 2002. Instituting Corporate Governance in Developing, Emerging and Transitional Economies - A Handbook. Center for International Private Enterprise.

COFFEE, J. C. JR. 2001. The rise of dispersed ownership: The roles of law and the state in the separation of ownership and control, Yale Law Journal, 111(1): 1-82.

CORPGOV. 2013. Improving accountability through democratic corporate governance since 1995. Corporate Governance. [Online]. Available at: https://www.corpgov.net/library/corporate-governance-defined [Accessed: 2016, May 14].

DAINES, R. and JONES, C. 2007. Mandatory disclosure, information asymmetry and liquidity: The effect of the 1934 Act. Working Paper. [Online]. Available at: http://www.law.yale.edu/documents/pdf/CBL/34_Yale.pdf [Accessed: 2017, June 22].

DAS, P. K. 2011. Towards Corporate Governance of Microfinance Institutions MFIs In India. Working Paper No. SRM/ KIIT/2. Orrisa. India: KIIT School of Rural Management, KIIT University.

DAVIS, F. G. and USEEM, M. 2000. Top Management, Company Directors, and Corporate Control. In: PETTIGREW, A., THOMAS, H. and WHITTINGTON, R. (Eds.). Handbook of Strategy and Management. Available at: http://www/ calpers-governance.org [Accessed: 2015, February 10].

FINANCIAL TIMES. 2011. Definition of Corporate Governance. The Financial Times. [Online]. Available at: http://lexicon.ft.com/Term?term=corporate-governance [Accessed: 2011, July 20].

GALLO, F., CHIACHIO, R. and CAVOUR MUNIZ, C. 2017. Corporate governance and directors' duties in Brazil: overview. UK Practice Law.

GEDALOVIC, E. and SHAPIRO, D. M. 2002. Ownership Structure and Firm Profitability in Japan, Academy of Management Journal, 45(2): 565-575.

GII. 2017. Global Innovation Index Report 2017. Global Innovation Index. Available at: https://www. globalinnovationindex.org [Accessed: 2018, February 2].

GILL, A. 2008. Corporate Governance as Social Responsibility: A Research Agenda, Berkeley J. Int'l Law, 26(2): 452-478.

GOERGEN FIDRMUC, J. P. M. and RENNEBOOG, L. 2006. Insider trading, news releases, and ownership concentration. The Journal of Finance, 61(6): 2931-2973.

GOWD, T. N., JITENDRA, G. and VENUGOPAL, B. 2011. Corporate Governance Practices in Indian Banks and Financial Institutions, Zenith International Journal of Multidisciplinary Research, 3: 5.

HABBARD, P. 2010. Corporate Governance in Brazil - An International Trade Union Perspective. Trade Union Advisory Committee. [Online]. Available at: https://members.tuac.org/fr/public/e-docs/00/00/06/F0/ document_doc.phtml [Accessed: 2016, November 15].

ICSI. 2017. Corporate Governance. [Online]. Available at: http://www.icsi.edu/ webmodules/icsiweb/works/ Schdiary/.../Corporate\%20Governance.doc [Accessed: 2017, October 10].

INSTITUTE OF DIRECTORS, SA. 2017. KING IV report on Corporate Governance. [Online]. Available at: https://c.ymcdn.com/sites/iodsa.site-ym.com/resource/collection/ .../IoDSA_King_IV_Report_WebVersion.pdf [Accessed: 2018, September 23].

JACKSON, H. E. and ROE, M. J. 2009. Public enforcement of securities laws: Preliminary evidence. Journal of Financial Economics, 93(2): 207-238.

KAR PRATIP, 2011, Dialectics of culture and corporate governance. Business Standard. [Online]. Available at http://www.business-standard.com/article/opinion/pratip-kar-dialectics-of-culture-corporate-governance [Accessed: 2014, March 15].

KHANNA, V. 2009. Law Enforcement and Stock Market Development: Evidence from India. CDDRL Working Papers. CDDRL.

KPMG. 2010. Corporate Governance Advisory in KPMG in India Corporate Governance Advisory Services. [Online]. Available at: https://home.kpmg.com/in /en/home/services/advisory/risk-consulting/governance-riskcompliance-services/corporate-governance-advisory.html [Accessed: 2016, May 29]. 
KULWINDAR, S. 2005. Foreign Direct Investment in India: A Critical analysis of FDI from 1991-2005. Centre for Civil society. [Online]. Available at: https:// papers.ssrn.com/sol3/ papers.cfm_id_822584 [Accessed:2016, August 20].

MAJUMDAR, S. K. and CHHIBBER, P. 1999. Capital structure and performance: Evidence from a transition economy on an aspect of corporate governance. Public Choice, 98(3-4): 287-305.

MALHERBE, S. and SEGAL, N. 2007. Corporate Governance in South Africa. [Online]. Available at: http://www. tips.org.za/publication/corporate-governance-south-africa [Accessed: 2016, August 25].

MILHAUPT, C. J. and PISTOR, K. 2008. Law and capitalism: What corporate crises reveal about legal systems and economic development around the world. Columbia Law and Economics Working Paper No. 313. Columbia university. [Online]. Available at: http://ssrn.com/abstract=987291 [Accessed: 2010, August 18].

NSE. 2005. Indian Securities Market - A Review ISMA. NSE India. [Online]. Available at: https: //www.nseindia. com/education/content/prs_publications.htm [Accessed: 2017, June 12].

OECD. 2004. OECD Principles of Corporate Governance. OECD. [Online]. Available at: https://www.oecd.org/ corporate/ca/corporategovernanceprinciples/31557724.pdf [Accessed: 2016, November 5].

PEDRONI, P. 2001. Fully Modified OLS for Heterogeneous Cointegrated Panels. In: Panel Cointegration and Dynamic Panels. Emerald Publishing, pp. 93-130.

RAJAN, R. G. and ZINGALES, L. 2003. The Great Reversals: The Politics of Financial Development in the 20th Century. Journal of Financial Economics, 69(1): 5-50.

RAY, A. 2018. How PNB Rs 11,300 crore scam exposes the biggest flaws in the Indian banking system. ET Bureau. The Economic Times. [Online]. Available at: http://economictimes.indiatimes.com/ articleshow/62938356.cms?utm_source=contentofinterest\&utm_medium=text\&utm_campaign=cppst [Accessed: 2018, February 22].

RAZEEN, S. 2017. Corporate Governance with Chinese Characteristics: The Case of State Owned Enterprises. University of Oxford. [Online]. Available at: https://www.law.ox.ac.uk/business-law-blog/blog/2017/05/corporategovernance-chinese-characteristics-case-state-owned [Accessed: 2018, February 22].

ROE, M. J. and SIEGEL, J. I. 2009. Political instability: Its effects on financial development, its roots in the severity of economic inequality. [Online]. Available at: http://papers.ssrn.com/sol3/papers.cfm [Accessed: 2012, August 18].

SASIDHARAN, S. and RAMANATHAN, A. 2007. Foreign Direct Investment and Spillovers: Evidence from Indian Manufacturing. MERIT Working Papers 010. United Nations University - Maastricht Economic and Social Research Institute on Innovation and Technology (MERIT).

SEBI. 2003. SEBI report on Corporate Governance. [Online]. Available at: http://www.sebi.gov.in/cms/sebi_data/ attachdocs/1293094958536.pdf [Accessed: 2017, January 2].

SIFUNA, A. P. 2012. Disclose or Abstain: The Prohibition of Insider Trading on Trial. Journal of International Banking Law and Regulation, 27(9): 340-535.

SOLANKI, G. A. 2012. Corporate Fraud: It's Time to Regulate. International Interdisciplinary Research Journal, 2(5): 138-142.

SWAPNA, S. S. 2007. Comparative Analysis of FDI in China and India: Can Laggards Learn from Leaders? Dissertation Thesis. Available at: www.bookpump.com/dps/pdf-b/1123981b.pdf [Accessed: 2017, January 13].

THOMSON, L. M. 2009. What is corporate governance? The Economic Times. [Online]. Available at: https:// economictimes.indiatimes.com/money-you/what-is-corporate-governance/articleshow/3995278.cms [Accessed: 2016, July 8].

UNADKAT, K. 2017. Top Ten Issues in Corporate Governance Practices in India. [Online]. Available at: http://www. acc.com/legalresources/ publications/top ten/tticgpi.cfm [Accessed: 2018, February 12].

VARMA, J. R. 1997. Jayanth Rama Varma report on Corporate Governance in India: Disciplining the Dominant Shareholder. [Online]. Available at: https://faculty.iima.ac.in/ jrvarma/papers/iimbr9-4.pdf [Accessed: 2016, July 9].

WORLD BANK. 1999. Corporate Governance: A framework for Implementation. Available at: https:// documents. worldbank.org/curated/en/831651468781818619/ pdf/30446.pdf [Accessed: 2018, February 12].

WORLD BANK. 2018. Corporate Governance in Transition Economies. Available at: http://documents.worldbank. org/curated/en/.../pdf/823220 REVISED00RMATOfinal019Mar2014.pdf [Accessed: 2018, September 23].

ZÖLLNER, C. 2013. Corporate Governance in China. [Online]. Available at: https://www.wiso.uni-hamburg. de/.../ECG_-_CG_in_China_FINAL.pptx[Accessed: 2016, July 5].

ZULIU, H. 1995. Stock market Volatility and Corporate Investment. IMF Working Paper. 95/102. IMF.

Pankaj Kumar Gupta:pkgfms@gmail.com

Shallu Singh: shallu9891@gmail.com 